\title{
Prof. Keith T. Oldham: solving problems can be a powerful motivator
}

Received: 16 October 2018; Accepted: 29 October 2018; Published: 09 November 2018.

doi: 10.21037 /jovs.2018.10.22

View this article at: http://dx.doi.org/10.21037/jovs.2018.10.22

\section{Editor's notes}

2018 ACS Clinical Congress is held from Oct 21 to Oct 25 in Boston Convention \& Exhibition Center. AME Publishing Company has participated in this Congress displaying our journals and books and meeting our editorial board members, authors and readers. The ACS Clinical Congress is the world's largest professional education and academic exchange for clinical surgery. Many outstanding surgeons gathered here to discuss the current application, advanced techniques and future development of surgery. During this Congress, we feel great honor to invite Prof. Keith T. Oldham (Figure 1), the Medical Director of the American College of Surgeons Children's Surgery Verification Program and Chair of the Verification Committee to share with us his story with the ACS Clinical Congress and his research work.

\section{Expert introduction}

Dr. Oldham completed undergraduate studies at the University of North Carolina as a John M. Morehead scholar in 1971. He received his MD from the Medical College of Virginia, completed general surgical residency at the University of Washington, Seattle, and trained in pediatric surgery at the University of Cincinnati Children's Hospital Medical Center. Dr. Oldham served on the faculty at the University of Michigan until 1991 when he was appointed Professor and Chief of the Division of Pediatric Surgery at Duke University. He remained at Duke until 1998 when he was recruited to the Marie Z. Uihlein Chair of Pediatric Surgery and the position of Surgeon-In-Chief at the Children's Hospital of Wisconsin. He has been a member of the American Pediatric Surgical Association (APSA) since 1985 and was elected Secretary in 1997 and President in 2012. He served as Chair of the Organization of Children's Hospitals Surgeons-in-Chief 2010-2012 and President of the Association of Pediatric Surgery Training Program Directors 2009-2011. He is actively involved in clinical outcomes and healthcare quality research,

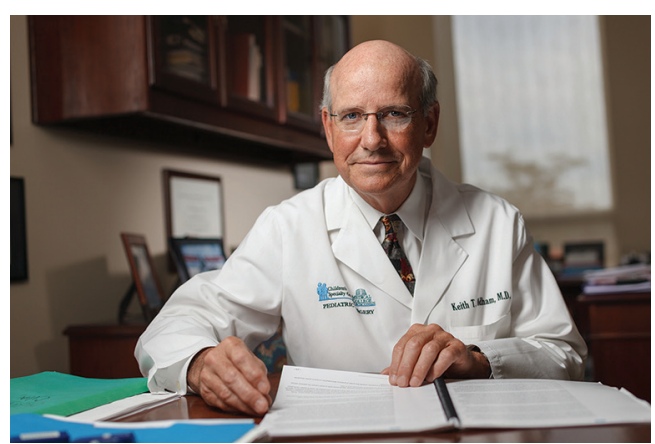

Figure 1 Prof. Keith T. Oldham.

including previous service as Chair of the ACS National Surgical Quality Improvement Program-Pediatrics Steering Committee. He is the Medical Director of the American College of Surgeons Children's Surgery Verification Program and Chair of the Verification Committee.

\section{Interview}

JOVS: Is it your first time participating in ACS Clinical Congress? If yes, what you expect and how do you feel? If not, when was your first time? What you did and how did you feel at that time?

Prof. Oldham: My first Clinical Congress was in 1981 when I was a Chief Resident in general surgery. I have attended most of the subsequent Congresses. My primary recollection of that first Congress was being overwhelmed with the many talks, videos, panel discussions and other activities, all of which I wanted to see and do. I knew then that I was going into pediatric surgery, but I still tried to do everything and be everywhere I could. I was not responsible for actually presenting or organizing anything then, but that has changed. My responsibilities have changed so I have become more selective and focused over the years, but it is still a time with more opportunities than I can take advantage of. 


\section{FOVS: What is the influence of ACS Clinical Congress on you?}

Prof. Oldham: Over the years it has been a wonderful venue to learn and also to connect directly with old friends and new colleagues. It has always been a time that I enjoy and value.

\section{FOVS: What sparked your interest in pediatric surgery?}

Prof. Oldham: Like most surgeons I was substantially influenced by several mentors during my education and training. Pediatric surgery specifically appealed to me because of the wide variety of problems one sees in general and thoracic pediatric surgery, as well as the ability to impact individual patients with decades of potential life ahead of them.

\section{FOVS: Can you introduce us to your most recent funded research, including its scope, purpose, duration of funding and current status?}

Prof. Oldham: I am at a point in my career where I no longer do basic science research, although I did so for many years in the general area of inflammation and vascular biology. My current research relates to the delivery of optimal children's surgical care to the children of North America and beyond. This is done in conjunction with colleagues in the American Pediatric Surgical Association, The Global Initiative for Children's Surgery, and the American College of Surgeons using population-based analyses and trying to identify resources associated with optimal clinical outcomes.

\section{FOVS: What are the most common challenges in research? And what would be your advice to young researchers?}

Prof. Oldham: For all investigators, finding adequate time and funding to conduct the research is an issue. For surgeons, competing clinical and administrative demands on your individual time are a particular issue. My one piece of advice for young researchers with regard to the latter issue is to find a professional environment where your work is valued by colleagues who will work with you to compartmentalize your obligations, including provision of dedicated time and resources to do your research work.

\section{Acknowledgments}

We would express our heartfelt gratitude for Prof. Keith T. Oldham for accepting our interview.

Funding: None.

\section{Footnote}

Provenance and Peer Review: This article was commissioned by the editorial office, Fournal of Visualized Surgery for the series "Meet the Professor". The article did not undergo external peer review.

Conflicts of interest: All authors have completed the ICMJE uniform disclosure form (available at http:// dx.doi.org/10.21037/jovs.2018.10.22). The series "Meet the Professor" was commissioned by the editorial office without any funding or sponsorship. All authors report that they're full-time employees of AME Publishing Company (publisher of the journal). The authors have no other conflicts of interest to declare.

Ethical Statement: The authors are accountable for all aspects of the work in ensuring that questions related to the accuracy or integrity of any part of the work are appropriately investigated and resolved.

Open Access Statement: This is an Open Access article distributed in accordance with the Creative Commons Attribution-NonCommercial-NoDerivs 4.0 International License (CC BY-NC-ND 4.0), which permits the noncommercial replication and distribution of the article with the strict proviso that no changes or edits are made and the original work is properly cited (including links to both the formal publication through the relevant DOI and the license). See: https://creativecommons.org/licenses/by-nc$\mathrm{nd} / 4.0 /$.

(Science Editors: Limor Fan, Silvia Zhou, Grace Li, JOVS, jovs@amepc.org)

doi: $10.21037 /$ jovs.2018.10.22

Cite this article as: Fan L, Zhou S, Li G. Prof. Keith T. Oldham: solving problems can be a powerful motivator. J Vis Surg 2018;4:233. 